LUCIEN DUPUIS

\title{
Francia y lo francés en la prensa periodica española durante la Revolución Francesa
}

Cuando estalló, en julio de 1789, la Revolución francesa, y sobre todo cuando ésta se encaminó hacia medidas cada vez más radicales y violentas, con el proceso y la ejecución del rey Luis XVI en enero de 1793, y con los principios del Terror en septiembre del mismo año, muchos en España triunfaron. No me refiero a los simpatizantes, sino a los adversarios más enconados, a aquellos que desde varios lustros venían declamando contra las ideas "perversas y corruptoras" que llegaban de más allá de los Pirineos. Triunfaron, porque vieron en los sucesos de Francia la confirmación de los temores que anteriormente habían expre- 
sado. Para ellos $-\mathrm{y}$ creo que muchas veces con entera buena fe--, los sangrientos sucesos que podían presenciarse aparecían como una consecuencia lógica, casi necesaria, de la ideología que llamaremos, para simplificar, enciclopedista. Los que siempre habían sido adversarios de las luces, de la nueva filosofía ilustrada, tuvieron la siguiente reacción: "Bien os decíamos que todo aquello era peligroso; ahí veis las consecuencias".

Hoy día, es difícil compartir esta opinión: la Revolución francesa no fue provocada por una ideología, sino por los problemas concretos de los que había surgido dicha ideología. Tampoco puedo admitir, por mi parte, que la adhesión de un sector de la opinión española a las nuevas ideas fuera consecuencia de un mero conlagio, que resultaba a su vez de no sé qué caprichoso gusto por lo francés. Lo que pasó en realidad fue que los mismos problemas concretos - aunque, claro, con matices distintos- se plantearon en España; y se plantearon más tarde que en Francia, por varios motivos, siendo los principales el que, por una parte, una economía menos avanzada no permitió en fechas tan tempranas la constitución de una potente clase burguesa, y, por otra parte, que la política ilustrada del reinado de Carlos III fue un intento en parte logrado de adaptación, que retardó la crisis del antiguo régimen. La consecuencia de esta diferencia cronológica, de este "retraso" si se quiere, es que, cuando los españoles se enfrentaron con sus propios problemas concretos y quisieron expresar y justificar las soluciones que éstos requerían, hallaron ya formuladas en Europa, y especialmente en Francia, las ideas que necesitaban. Y eso es lo que pudo dar la impresión de imitación y lo que, si no ahondamos, podría hacernos creer que una ideología extranjera, por sí misma, luvo un impacto suficiente para destruir el antiguo régimen, cuando en la mayoría de los casos no sirvió más que 
para suministrar unas formulaciones adecuadas al planteamiento de cuestiones surgidas de la propia realidad española. (No creo que puedan exportarse las revoluciones por la propaganda y la difusión de las ideas, si no existen ya circunstancias objetivas para la revolución. Dicho de otra manera, la difusión y aceptación de determinadas ideas suele ser más bien síntoma que causa).

En realidad, si la Revolución francesa señaló para al. gunos españoles nuevas metas que alcanzar, y también escollos que debían evitarse, lo que pudo ser su resultado más inmediato $-\mathrm{y}$ no es aventurado pensar que en efecto lo fue en alguna medida - fue truncar, por la indudable reacción que provocó, el movimiento general de la corriente ilustrada en España antes que éste llegara a producir sus frutos naturales. Por eso es interesante examinar el contenido de la prensa periódica contemporánea a los acontecimientos revolucionarios, dado el importantísimo papel que hasta entonces habían desempeñado sus redactores en la difusión de las "luces" y la ampliación del público alcanzado por ellas.

Como se sabe, Floridablanca quiso impedir toda discusión pública sobre los sucesos de Francia. Su política fue la del silencio, hasta tal punto que se opuso a que circularan incluso los escritos destinados a combatir las teorías revolucionarias, porque ello suponía que se aludiera a ellas. El despotismo, aunque fuera ilustrado, se sentía amenazado. Para la difícil tarea de vigilancia que imponía la voluntad de cortar el paso, no sólo a las doctrinas subversivas, sino a las meras noticias de lo que ocurría en Francia, el Gobierno solicitó la ayuda de la Inquisición, la cual, como era de esperar, no había tardado en reaccionar (el Edicto 
prohibitivo de 13 de diciembre de 1789 , tras enumerar 41 títulos de escritos franceses, extiende la condenación a cuantos papeles pudieran en adelante relacionarse con las doctrinas revolucionarias). Desde luego, hacía tiempo que los calificadores de la Inquisición se preocupaban por la defensa del orden político y social, e identificaban la defensa de la Religión con la del Estado absoluto. Pero había existido un mutuo recelo y una tensión grave entre la Inquisición y el poder Real, sobre todo desde las providencias de 1762 y 1768, cuyo fin era limitar las atribuciones del Santo Oficio y colocarlo bajo el control de la autoridad civil, especialmente en materia de censura. Un informe redactado en 1769 por los fiscales del Consejo de Castilla - entre los cuales Campomanes--- había llegado a afirmar que el Rey podría incluso suprimir la Inquisición si lo considerase útil. ${ }^{1}$ Por lo tanto, la nueva colaboración de hecho, que pronto iba a ser legalmente organizada, ${ }^{2}$ señala un evidente cambio de orientación y es buen indicio de los temores que se experimentaban en los medios gubernamentales. No es del caso enumerar las numerosas providencias tomadas, ya desde septiembre de 1789 y en los años sucesivos, para que España quedara a salvo del posible coniagio. ${ }^{3}$

I. Véase Marcelin Defourneaux, L'Inquisition espagnole et les livres français au XVIIIe siècle, París, P. U. F., 1963, pág. 62.

2. Resolución del 15 de octubre de 1792, Novísima Recopilación, Libro VIII, Título XVIII, Ley XIV.

3. Remito al libro de Richard Herr, traducido con el título de Espa. ña y la perwatución del sigta XVIII, Aguilar, 1964 (véase en especial el cap. VIII, "El pánico de Floridatiaticia"). Sobre la difusión y los efectos de la propaganda revolteionatia en España purden consultarse, además de dicha obra, Jean Sarrailh, L'Espagne étaire de la seconde montié du XVllle siècle, París, 1954 (págs. 600-61l sobre todo); Miguel Artola, "La difusión de la ideología revolucionaria en los orígenes del liberalismo español", en Artor, XXXI (1955), pág, 476-490; Carlos Corona, Revolucitín y reacción en el reinzlo de Carlos IV (Rialp, 1957), Jaequelime Chaumié, Les relations diplanuzriques entre l'Bspagne et la France, de Varennes d̀ la mart de Loust XVl, P’aris, 1957, y Gonzalo Anes Alvarez, "Ecos de la Re. valución froncesa on Espuña. Algumos datos $Y$ documentes", en Cuadernos 
Lo que sí debe recordarse aquí, es la Real resolución del 24 de febrero de 1791, por la cual quedaban suspendidos todos los periódicos no oficiales: "Con motivo de advertirse en los Diarios que salen periódicamente, haber muchas especies perjudiciales; cesen de todo punto, quedando solamente el Diario de Madrid de pérdidas y hallazgos, ciñéndose a los hechos, y sin que en él se puedan poner versos, ni otras especies políticas de cualquiera clase". ${ }^{4}$ Semejante disposición significaba algo más que un simple deseo de precaverse contra la subversión, ya que la prensa periódica, sometida a la censura previa y estrechamente vigilada, difícilmente podía considerarse peligrosa desde aquel punto de vista. El golpe, por consiguiente, iba dirigido contra el movimiento intelectual; era una medida indudablemente reaccionaria, una condenación implícita de toda la política de ilustración, que el propio Floridablanca había propugnado durante muchos años. En efecto, si éste, en un principio, sólo intentó contener el flujo de publicaciones revolucionarias o alusivas a la Revolución, había llegado a revalorar la política de la Corona respecto a las "luces" en general, y a modificar radicalmente su actitud hacia la ilustración nacional. El mismo explicaba en una carta al conde de Fernán-Núñez, el representante de España en el París revolucionario: "Se dice que el siglo ilustrado

de Historia de España (Facultad de Filosofía y Letras, Buenos Aires), 1962, págs. 274-314.

Naturalmente, la política de silencio iniciada por Foridablanca no pudo tener resultados duraderos, y la curiosidad por los acontecimientos de la nación vecina acabó por cundir a todas las clases, si hemos de creer testimonios como el del Padre Estala, quien escribía con gracis a Forner en 1795: "en las tabernas y en los altos estrados, junto a la Mariblanca y en el café, no se oye más que batallas, revolución, convención, representación nacional, libertad, igualdad. Hists las p... te preguntan por Robespierre y Barrère, y es preciso llevar una butena dosis de patrafias gacetales para complacer a la moza que se corteja." (B.A.E., tomo LXI, pág. CCII).

4. Novisima Recopitación, Libro VIII, Título XVII, Ley V. Siguieron publicántose los periódicos oficiales (Gaceta de Madrid y Mercurio de Es. paña), pero sin aludir, claro está, a los sucesos de Francia. 
ha instruido al hombre de sus derechos, pero le ha quitado, con la verdadera felicidad, el reposo y seguridad de su persona y familia. Nosotros no queremos aquí tanta ilustración, ni lo que trae como consecuencia: insolencia de los actos, de las palabras y de los escritos contra los Poderes legítimos". Somo dijo Herr, "el hedor que llegaba de allende los Pirineos había contaminado todas las ideas de reforma, tanto extranjeras como domésticas, y todas repugnaban a los gobernantes". 6

Sin embargo, no todos los ilustrados españoles reaccionaron de manera tan tajante. Muchos de ellos, para quienes la Revolución vecina fue indudablemente una crisis que puso a prueba sus ideas, no cantaron la palinodia; aun cuando condenaron los sucesos revolucionarios por su as. pecto de desorden y violencia y se dieron cuenta horrorizados de que no habían querido aquello, no renegaron de sus ideales ni renunciaron a sus aspiraciones de una reforma profunda, aunque gradual y pacífica. En 1794, Jovellanos escribía a Jardine que los españoles tendrían derecho a aspirar no sólo a un Gobierno moderado a la inglesa, "sino por ejemplo a una constitución cual la que juró Luis XVI en 1791". Siempre seguirá distinguiendo entre los excesos de la Revolución y ciertos principios legítimos a que ésta obedeció; así escribirá en 1809, refiriéndose a la convocación de Cortes: "Ni el triste ejemplo de la Francia nos debe intimidar para que no recurramos a tan saludable medida; porque, ¿quién ignora que todos los males de aquella revolıción fueron efecto de la imprudencia de su Gobierno? (...) Si seguimos la historia de la asamblea constituyente, hallaremos que su objeto no era

5. Cit. por Albert Mousset, Un témoin ignoré de la Révolution française: le comte de Fernán Núñez, ambassadeur d'Espagne à Paris (1787. 1791), Paris, 1924, pág. 49.

6. Richard Herr, loc. cit., pág. 217.

7. B.A.E., lomo L, pág. 367 a. 
otro al principio que la reformación de abusos ciertos y conocidos". ${ }^{8}$ Menos todavía aceptó Jovellanos que España, con motivo -o con pretexto- de la Revolución, fuese privada del contacto con la moderna cultura europea que le llegaba por el conducto de Francia; contestando a unos reparos que se le pusieron a su Oración inaugural en la apertura del Real Instituto asturiano, escribía en 1796: "Tanto me ofenden los que quieren que el pueblo lo sea todo, como los que no quieren que sea algo: tanto los que quieren cortar los abusos con la segur, como los que quieren defenderlos con el escudo, o cubrirlos con la capa. La verdad es de todos los tiempos y países, y el hombre le debe su res. peto en todos los estados y condiciones; pues si hubieran enamorado al autor ciertas expresiones en otro tiempo, ¿por qué no ahora? Porque los libros franceses... ¡Válgate Dios por franceses, y qué extraño partido se quiere sacar de sus lecturas! ¿Acaso porque ellos fueron frenéticos, seremos nosotros estúpidos?". Incluso un hombre como Antonio de Capmany —el futuro autor de Centinela contra franceses - se negaba entonces a detestar todo lo francés y a amalgamar, como algunos quisieran, la cultura francesa en su conjunto con las teorías revolucionarias. En un informe de censura para el tomo X de la Historia crítica de España de Masdeu, le achacaba su actitud sistemáticamente anti-francesa y el poco decoro con que trataba a unos autores célebres $;^{10}$ este informe lo redactaba en junio de 1794, o sea en el momento más sangriento del Terror.

Entre los que, a pesar de la Revolución francesa, per.

8. Consulta sobre la convocación de las Cortes por estamentos, Apéndice núm. XII a la Memoria en defensa de la Junta Central (B.A.E., tomo XLVI, pág. 599 b.)

9. Carta a Carlos González de Posada, 1. de junio de 1796 (B.A.E., tomo L, pág. 195).

10. Véase en la Real Academia de la Historia, Censuras pedidas por el Consejo a la R.A.H., legajo 10, núm. 54. 
manecieron fieles a sus principios y quisieron seguir promoviendo la ilustración nacional, hemos de contar al conde de Aranda. Lo demostró cuando, poco después de sustituir a Floridablanca en febrero de 1792, tomó una serie de medidas cuya orientación era bien distinta de la política úl. timamente mantenida por éste. " Una de ellas nos in. teresa ahora directamente: el permiso que dio Aranda -y que luego mantuvo Godoy- para que reapareciera la prensa periódica nacional. Así vieron la luz, el $1 .^{\circ}$ de septiembre de 1792, el Correo literario de Murcia (después de un Diario de Murcia, desaparecido en 30 de abril) y el Diario histórico y politico de Sevilla; el $1 .^{\circ}$ de octubre de 1792, el Diario de Barcelona y el Correo mercantil de España y sus Indias; el 1. de julio de 1793, la continuación del Memorial literario, instructivo y curioso de la Corte de Madrid; el 1..$^{\circ}$ de octubre de 1793, el Semanario erudito y curioso de Salamanca; el 5 de febrero de 1795, el Correo de Gerona. De otros periódicos de la época, ${ }^{12}$ sólo pude ver números suelios.

El examen del contenido de estos periódicos ${ }^{13}$ es interesante por varios motivos. Por una parte, nos puede proporcionar una respuesta parcial a la cuestión de saber cómo se consideró en España lo que se relaciona con la Revolución francesa. Por otra, permite apreciar en qué medida las ideas de la Ilustración sobrevivieron al choque,

11. Salvó de la Inquisición a Mariano Luis de Urquijo, que había publicado a fines de 1791 la traducción de una tragedia de Voltaire, La muerte de César. Mitigó la desconfianza existente entre España y Francia. Dejó que entrasen de nuevo en España los súbditos franceses, y que llegasen por el Servicio de Correos los periódicos de Francia.

12. Números sueltos del Correo de Cádiz (desde 1795 a 1798), del Diario de Valencia, desde 1795 a 1810 (pero existe un volumen intitulado Colección de algunas piezas interesantes al Diario de Valencia, que lleva la fecha de 1793), y tres números de Palma de Mallorca que llevan, junto a la fecha de 1795 , la mención "Año XVII".

13. Quiero hacer constar que muchos de los datos que manejo en lo que sigue han sido reunidos por la Srta. Nicole Cabanac, en un estudio que realizó bajo mi dirección para el "Diplôme d'Etudes Supérieures". 
qué resistencia opusieron sus defensores a las tentativas de reacción más o menos ciega propugnada por algunos. En fin, nos da una imagen de muchos aspectos de la vida intelectual, encontrándose en esta prensa el reflejo de muchos debates, y no solamente de una actitud determinada, que sería la de sus redactores, hombres ilustrados por lo general. En efecto, la práctica corriente de insertar cartas o artículos remitidos por los lectores hace que aparezcan en un mismo periódico opiniones a veces diametralmente opuestas; por lo tanto, estos periódicos se convierten en una especie de tribunas para la discusión pública, dentro, naturalmente, de los límites impuestos por la censura previa. Tanto la existencia de dicha censura, como la evidente dificultad de expresar en aquel momento unas simpatías abiertas hacia las ideas procedentes de Francia (sobre todo durante la guerra hispano-francesa), deben tenerse en cuenta para interpretar los textos publicados y para invitar a leer entre líneas lo que quieren insinuar los artículos, por no poder decirlo a las claras. Ocurre también que el sistema de los "artículos remitidos" sirve para disimular, y en muchos casos es casi imposible distinguir entre lo que realmente se debe a la pluma de un lector anónimo y lo que escribieron los propios redactores valiéndose de este disfraz. Bien reveladora es la siguiente nota que aparece en el Correo de Gerona: "Para no confundir esta carta con otras que se han supuesto dirigidas al despacho de este periódico, se advierte que verdaderamente se ha recibido en él."."14

Hechas estas advertencias, pueden distinguirse, dentro del contenido de estos periódicos, varias orientaciones respecto de Francia y de lo francés. Existe una actitud extremista de rechazo total, de repliegue y de reacción, que qui-

14. Núm. 37 (1l de junio de 1795), pág. 1. 
siera cerrar las puertas de España a todo el pensamiento europeo e incluso poner en tela de juicio la validez de todas las ideas que inspiraban la política ilustrada desde el reinado de Carlos III. O sea que vuelve a surgir lo de "los aires infectos del Norte" que ya indignaba a Feijoo. Cabe sospechar que la cruzada antirrevolucionaria fue, para todo un sector ideológico, ocasión y pretexto para una marcha atrás, una aniquilación del pensamiento ilustrado e incluso una vuelta al oscurantismo. Por otra parte, estos periódicos reflejan la continuación de las discusiones orientadas hacia la reforma de los abusos y ofrecen muchos indicios del renacimiento del espíritu de las luces. Como ya en la prensa periódica del final del reinado anterior, se dan auténticos debales sobre temas científicos, económicos y filosóficos que no es mi propósito estudiar aquí. ${ }^{15}$ Esta corriente ilustrada sigue recurriendo a fuentes y ejemplos europeos, muchas veces franceses, por lo cual tiene que manifestarse a pesar del ambiente, evidentemente adverso, debido a la guerra. Se trata otra vez de una verdadera contienda ideo. lógica que, superficialmente, opone partidarios y adversarios de la cultura europea y, en realidad, progresistas y reaccionarios.

La política de silencio acerca de todo lo referente a los acontecimientos de Francia fue mantenida en un principio por el gobierno de Aranda y luego por el de Godoy, incluso después de declarada la guerra: ${ }^{16}$ parecía preferible a los gobernantes que el pueblo ignorase los cambios políticos y las reformas que se verificaban en el país vecino.

15. Sobre el resurgimiento de la ilustración a través de la prensa periódica, véanse las sugestivas páginas de Richard Ierr (op. cit., págs. 292-294).

16. En 7 de junio de 1793 "se prohibió insertar, en papel o libro que se imprima, noticias algunas favorables o adversas de las cosas pertenecientes al reino de Francia". (Novísima Recopilación, Libro VIII, Título XVIII, Nota 18 a la Ley XIII); esta Orden fue reiterada el 17 del mismo mes, y otra vez el 28 de julio (ibid.. notas 19 y 20 ). 
Sin embargo, esta táctica se vio algo modificada por la necesidad de despertar el entusiasmo popular hacia la guerra, de justificar ésta como una cruzada contra los enemigos de la religión. El silencio oficial se había roto al anunciarse por la Gaceta tres meses de luto en la corte "con motivo de la muerte de Luis XVI, Rey Cristianísimo de Francia, que terminó su carrera el día 21 de enero próximo pasado con una heroicidad igual a sus anteriores infortunios y a la inhumanidad del horrendo e inaudito atentado cometido contra su augusta persona"; ${ }^{17}$ pero todavía en febrero de 1794 el Gobierno mandaba recoger una traducción de La vida y muerte de Luis XVI, de "Mr. Simón", que se estaba imprimiendo en Orihuela por los editores del Correo literario de Murcia. ${ }^{18} \mathrm{El}$ dilema era éste: hacía falta animar a los españoles a la guerra contra la Revolución y, al mismo tiempo, evitar que se filtrase el contenido político y social de esta revolución. Por eso, en el primer período de la prensa que había vuelto a aparecer, la campaña antirrevolucionaria de inspiración gubernamental no consiste en una discusión de los principios revolucionarios, sino más bien en unos ataques generales y vagos a la "nueva filosofía" y a la "irreligión", y en unas invectivas contra la "raza maldita" de los franceses. Servirán de ejemplo los siguientes versos:

Que ahora dar la carga determino

A la gente peor y más dañosa

Que del infierno va por el camino.

Raza insolente, peste contagiosa,

Generación inicua ultramontana,

A todo el mundo con razón odiosa. ${ }^{19}$

17. Gazeta de Madrid, 5 de febrero de 1793.

18. Novísima Recopilación, loc. cit., nota 22.

19. Correo literario de Murcia, núm. 1 (1..$^{\circ}$ de setiembre de 1792), pág. 5, "Sátira". 
No es útil insistir mucho sobre los numerosos artículos dedicados a la denuncia virulenta de todo lo francés: es el aspecto más conocido y, en parte, la continuación de un tema nada nuevo, sobre todo cuando se refiere a unos aspectos bastante superficiales, como las modas, los usos, el empleo de galicismos. Sólo que las circunstancias daban pie para denunciar también el peligro de disolución de la sociedad que se suponía envuelto en la afición a las modas. En un artículo que aparece primero, firmado D. B. L., en el Correo de Murcia, y poco después, sin firma, en el Semanario de Salamanca, leemos: "Cuando esperábamos que los disparates de nuestros vecinos transpireneaicos hubieran acarreado entre nosotros una justa detestación de sus modas y de todo cuanto pudiera tener relación con su modo de pensar, vemos que a pesar nuestro se nos han de estar refregando por estas barbas sus modas y su modo". ${ }^{20}$ Otro artículo del Correo de Murcia censura la moda como vehículo de otra corrupción más honda y peligrosa; su autor, dirigiéndose a España, dice: "Abiertas tus puertas a un comercio perjudicial, en que recibías todos los instrumentos de lujo y vanidad, a trueque de lo más precioso de tu sangre, halló la malignidad resquicio por donde, a pesar de tu cuidado y vigilancia, introducir el veneno bajo un aspecto agradable: así logró insinuar blandamente en los ánimos de los jóvenes incautos, no sólo el amor a la extravagancia en el vestir, sino, lo que es peor, en el discurrir y obrar". ${ }^{21}$ Y una carta a los editores, que aparece tanto en el Correo de Murcia como en el Semanario de Salamanca, advierte que,

20. Correo literario de Murcia, núm. 226 (28 de octubre de 1794), tomo VII, pág. 133; y Semanario erudito y curioso de Salamanca, núm. 121 11 de noviembre de 1794), tomo V, pág. 93; "Las modas".

21. Núm. 145 (18 de enero de 1794), tomo V, págs. 39-40: “La moda más lamentable", firmado "M.M.M.". 
"siendo los adornos de la guillotina y escarapela en sus originales un efluvio o un resultado del espíritu de irreligión y de inhumanidad que circula por el corazón de la mayor parte de las ultramontanas, es como natural el que se piense la misma corrupción en cuantas las imiten", y pide "la censura de estos abominables nombres, repitiendo que por sí mismos saben a adhesión o indiferencia en los asuntos de Francia". 22 Aun pareció peligroso a algunos el interés despertado en España por una invención francesa tan poco política como la del telégrafo, que Barrère había anunciado en la Convención. Según un artículo del Correo de Murcia, "no se puede describir sin enfado el maniático entusiasmo de algunos críticos eruditos de la época, que aturdidos de la novelería e imbuidos en las máximas de una indiscreta preocupación, se lisonjean de parecer íntimos admiradores de todo lo que tiene visos de extraño y huele a los filósofos perfumes ultramontanos"; para el redactor, los admiradores de aquella invención eran unos "díscolos y afilosofados sapientes Galliam", "23 lo cual viene a ser un poco como si, hace algunos años, se hubiera considerado peligroso o políticamente sospechoso el interés despertado por el primer Sputnik.

No me detendré solbre el aspecto de propaganda antirrevolucionaria, aunque, en los momentos de mayor tensión (primavera y verano de 1793, verano de 1794), los artícu-

22. Correo...de Murcia, núm. 260 (24 de febrero de 1795), tomo VIII, pág. 119; y Semanario de Salamanca, núm. 168 (16 de abril de 1795), tomo VIf, pág. 53. Es de suponer que la escarapela que llevaban estas españolas en la cabeza sería tricolor, como la de los revolucionarios franceses. Fn cuanto al "pañuelo a la guillotina", tenemos algana idea de él por un artículo ya mencionado (véase la nota 20), donde se lee: "La endemontada idea de ponerse en las chalecos una doblo solapa, regularmente carmesi, que imita con hastante naturalidad los efectos de una cabeza degollada, cuya sangre baña el cuello y pecho, es a lo que podía haber Hegado la locura de mis patsanos; y decorar esta moda con el nombre de Guillotina me parece que es el cúmulo de la depravación".

23. Núm. 235 (29 de noviembre de 1794), tomo VII, pág. 208; "El telégrafo y su mecanismo", firmado "El M.E.". 
los de este tipo constituyen una proporción importante del contenido de los periódicos: por ejemplo, en la primavera de 1793, casi la mitad en el Diario de Barcelona. Se insertan sermones, pastorales, llamamientos a la contribución para la guerra, etc. Era una obligación a la que no podían sustraerse los editores, pero no habían fundado los periódicos para este fin, y es de notar que los artículos más reaccionarios son los mandados por algunos lectores y que muchas veces los editores estampan a continuación su propio parecer, contestándoles en sentido más ilustrado.

Sólo quiero subrayar cómo las circunstancias son para algunos ocasión de condenar la ilustración en bloque, como sospechosa de procedencia francesa. Un corresponsal del Correo de Murcia que firma "El de las calzas alacadas" añora "el estado feliz de nuestra España en el tiempo en que se miraba poseída de españoles", mientras que ahora "el morbo gálico ha penetrado ya hasta los más pequeños intersticios, y los humores viciosos han invertido todo el mecanismo del cerebro. Ya las lluvias intempestivas, las sequedades prolongadas, las inundaciones soberbias, los terremotos espantosos, las tempestades desoladoras, las carestías excesivas, las enfermedades violentas, las guerras devastadoras, todos son efectos de la casualidad según los españoles ilustrados, y no en ningún modo la voz terrible de un Dios que nos amenaza". Como puede apreciarse por los argumentos, que pertenecen a una mentalidad propia de la España anterior a Feijoo, se trata de un ataque, no ya contra las doctrinas revolucionarias, ni siquiera contra la nueva filosofía, sino contra el mismo ideal de ilustración, que conduce al muy significativo elogio de una ceguera voluntaria: "Milagro es a la verdad que, a unas luces en que todas las pasiones a la vez se ven realzadas con los más vivos y agradables coloridos, haya todavía algunos ciegos españoles, que por fortuna no hayan abierto sus ojos sino 
para llorar amargamente la ilustración, mejor diré deslumbramiento, de tantos seducidos paisanos y corregnícolas". ${ }^{24}$

No muy lejos de esta posición de reacción a ultranza andaba un lector del Diario de Barcelona al preconizar un aislamiento de España, manifestando así la típica falta de confianza de los que creen que la verdad — su verdad- carece de la fuerza propia de la evidencia para imponerse contra la seducción del error: "Señor diarista, salto de gozo y contento al ver lo que usted en sus periódicos se emperra por remendar la mala moral del día, y por combatir los malos principios que se han soltado del lado de allá de los Pirineos, que, como tan lisonjeros a las pasiones de los hombres, pueden causar mucho mal a nuestras costumbres y sistema, si por todos los medios imaginables no se cuida de poner un cordón más estrecho que el que se establece para contener el humor pestilencial, que bloquee todos los sentidos de nuestros sanos compatriotas". ${ }^{25}$

Significativas de este repliegue, en el terreno cultural, son las invitaciones a una vuelta al estudio y conocimiento de la antigüedad. El tema se relaciona con las quejas, nada nuevas por cierto, acerca de la adulteración de la lengua castellana por el uso de galicismos. El Memorial literario anuncia a sus lectores una Declamación contra los abusos introducidos en el castellano, según la cual las causas de la decadencia del lenguaje son "el olvido de nuestros originales, poco estudio de la latinidad y demasiada aplicación a la lengua francesa". ${ }^{26}$ En el Diario de Barcelona se denuncia el nuevo lenguaje "gali-español" que cunde, y se

24. Núm. 171 (19 de abril de 1794), tomo V, págs. 243-246.

25. Núm. 216 (4 de agosto de 1793), tomo II, pág. 889; carta de Francisco Caso de Noriega al redactor.

26. Continuación del Memorial literario..., agosto de 1793 (parte $1 .^{\text {a }}$, tomo I, pág. 182); "Libros nuevos". 
satiriza a los que se creen obligados a decir "ui musie en lugar de sí señor". ${ }^{27}$ El Semanario de Salamanca intenta predicar una vuelta a la literatura greco-latina, diciendo que "si han sido poetas los Volteres y Roseaux (sic), hombres indignos de este triste papel, también lo han sido los Prudencios y Prósperos, y otros infinitos que honran nuestros altares y bibliotecas. ¿Quid plura?" ${ }^{28}$ El Memorial literario, al presentar a sus lectores Los diez libros de Dió. genes Laercio, traducidos por José Ortiz y Sanz, juzga que éste "declama con razón en el prólogo contra la demasiada aplicación de nuestros españoles a traducir obras francesas, sin llegar a las más privilegiadas que son las griegas, de quienes ha dimanado toda erudición." Y comenta el diarista: "Atribuye esta aplicación a efecto de lo que dijo el P. Feijoo, que era más fácil aplicarse al francés que a la lengua griega. (...) Pero pueden haber contribuido otras causas, como son (...) la moda o costumbre introducida por el comercio de los libros franceses; el ejemplo de los predicadores que han imitado el estilo francés; la abundancia de libros místicos franceses escritos con otra novedad y estilo de los que tenemos castellanos, y, lo que nos parece un motivo más fuerte, el poco gusto de los nuestros en las humanidades..."29 Merece destacarse lo que se dice aquí de la influencia francesa en el terreno de la literatura religiosa. Ello nos recuerda de manera muy oportuna que el contenido de la invasión cultural francesa no se limitó a las ideas del enciclopedismo o a las doctrinas revolucionarias, como algunos decían y aún siguen diciendo; no puede olvidarse que simultáneamente se imitaban en España los

27. Núm. 332 (28 de noviembre de 1793), tomo II, pág. 1354; "Dis. curso sobre los sabios a parentes", firmado "B.B.".

28. Núm. 139 (13 de enero de 1795), tomo VI, pág. 26; firmado "Pedro Alonso y la Avecilla".

29. Marzo de 1794 (parte 1. ${ }^{\mathrm{a}}$, tomo III, págs. 383-384); "Libros nuevus". 
libros franceses de apologética católica, los tratados o folletos antifilosóficos, y que se tradujeron numerosas obras de Barruel, Bergier, Feller, Guyon, Jamin, Nonnotte, etc. La verdad es que ambos bandos, en la contienda ideológica, acudieron a fuentes francesas.

Después de ilustrar someramente esa actitud negativa de los que propendían a rechazar todo lo francés y, a veces, a través de lo francés, lo europeo y las luces en general - actitud más propia de algunos lectores que de la mayoría de los redactores de los periódicos-, conviene ahora mostrar cómo éstos, a pesar de las circunstancias muy poco propicias, siguieron dando a conocer muchos aspectos de la producción de las prensas europeas y en particular francesas. Sólo daré unos cuantos ejemplos, sin ignorar, por otra parte, que el hecho de que los periódicos diesen noticia de la aparición de determinadas obras francesas no arroja mucha luz sobre la aceptación de las ideas que en ellas se desarrollaban; sólo es un motivo para creer que se conocerían y difundirían. En cualquier caso, es una prueba de que no se desanimaron aquellos que querían ver realizados en España los adelantos científicos y económicos logrados en Europa antes de 1789, aun cuando no aprobasen la revolución política de Francia.

Entre las obras de teatro cuya representación se anuncia en el Memorial literario citaré la Semíramis que, dado el anonimato, parece ser la de Voltaire; ${ }^{30}$ del mismo autor, aunque se calla su nombre, es "El falso profeta Maho$m a$, tragedia traducida del francés", anunciada por el Semanario de Salamanca; ${ }^{31}$ el Memorial literario da noticia de la traducción de "la comedia en prosa El hijo na-

30. Diciembre de 1793 (parte 2. ${ }^{\text {, }}$ tomo II, págs. 465-466; "La Semiramis, tragedia en un acto. Más bien puede decirse el último acto de la tragedia Semíramis."

31. Núm. 60 (26 de abril de 1794), tomo III, pág. 71. 
tural o pruebas de la virtud, de Diderot". ${ }^{32}$ El mismo periódico ofrece un "Extracto razonado del Tratado de las sensaciones por el abate Condillac y traducido por el L.D.J.R.L. y V., subrayando el valor de la obra y lamentando lo limitado del extracto. ${ }^{33}$ El Diario de Murcia publica, bajo el título "Elogio de Jesuchristo que la fuerza de la verdad hizo confesar a un filósofo impío", un extracto del Emilio de Rousseau. ${ }^{34}$ El Correo de Gerona propone a sus lectores dos extractos de la Enciclopedia. ${ }^{35}$ En el Correo de Murcia se hace el elogio de las sociedades científicas establecidas en Francia y, hablando del Journal des Savants, se dice que en aquella colección "se encuentra todo lo mejor que se ha escrito en estos últimos tiempos". ${ }^{36}$

Para los editores, mantener el contacto con la cultura francesa era la condición del progreso de las luces en España. Mucho lo repitieron porque, como hemos visto, necesitaban justificarse e ir en contra de una corriente muy fuerte. En julio de 1793, al solicitar del Consejo el permiso para publicar un periódico titulado "El Académico", Meléndez Valdés y otras cinco personalidades literarias manifiestan su deseo de "despertar la curiosidad y el talento de nuestros españoles y encaminarlos hacia la verdadera y sólida instrucción, poniéndoles delante los progresos que dan en ello otros pueblos, y las ventajas que de ello les resultan". Protestan de su intención de trabajar "para la utilidad, y respetando, si es lícito decirlo, hasta la misma preocupación", lo cual no impide que ataquen abiertamente a los que llaman "las gentes preocupadas que no alcanzan a

32. Marzo de 1794 (parte 2. ${ }^{a}$, tomo III, pág. 463).

33. Mayo de 1794 (parte 1.a, tomo IV, pág. 212).

34. Núm, 22 (22 de enero de 1792), tono I, págs. 86-87.

35. "Discurso sobre la guerra, extractado de la Encyclopedia", tumo II, Núm. 21 (16 de abril de 1795), págs. 11.12 y núm. 23 (23 de abril), págs. 1-7. "Guerrero. Artículo extractado de la Encyclopedia", tomo II, núm. 45 (9 de julio de 1795), págs. 1.5.

36. Núm. 207 (23 de agosto de 1794), tomo VI, págs. 261.264. 
distinguir las luces del abuso que de ellas puede hacerse"; y en el Prospecto del periódico, que va adjunto a la petición, puede leerse: "Creemos firmemente, y por honor de la razón, que el saber no perjudicó jamás a ninguno, y que el adelantamiento de las ciencias o las artes, de las fábricas, el comercio o la industria, de la población, de la fuerza y riqueza de los Estados es a un mismo tiempo la verdadera felicidad de los pueblos y de los soberanos que los gobiernan", ${ }^{37}$ con lo cual parece insinuarse que la monarquía corre el riesgo de desaparecer, o por lo menos de sufrir trastornos, si no sigue siendo ilustrada.

Como muestra de esta corriente de pensamiento, que enlaza con la habitual en la prensa de la época de Carlos III y que se muestra rebelde a la reacción o al aislamiento cultural, citaré un artículo del Diario de Barcelona cuyo autor (que firma - digámoslo así-- "Fulano") increpa en los siguientes términos a los encarnizados enemigos de todas las novedades: “¿Cuál es vuestro designio? ¿Qué esperáis de vuestra rabia y obstinación? Cuando hayáis desanimado a los autores célebres y a los ingenios sobresalientes que quedan en la nación, ¿qué haréis en recompensa por ella? ¿Cuáles son las obras admirables que presentaréis al género humano en lugar de la que hubiera obtenido de aquéllos? A pesar vuestro, los nombres de Buffon, de Daubenton, de Duclos, de Newton... serán honrados entre nosotros y entre nuestros nietos, y, si alguno se acuerda de los vuestros, será para decir: "Estos fueron los enemigos de los primeros hombres de su tiempo; y si poseemos la historia de la Naturaleza, los principios matemáticos, el espíritu de las leyes, etc., etc., es que por fortuna no estaba en la mano de tales gentes el privarnos de ellos". ${ }^{38}$ Más atrevido toda.

37. A.H.N., Consejos, leg. 5559, núm. 87. Véase Georges Demerson, Don Juan Meléndez Valdés et son temps, Paris, 1962, págs. 193.196.

38. Núm. 310 (6 de noviembre de 1793), tomo II, págs. 1265-1266. 
vía es un artículo firmado "El amigo de la verdad", que aparece en el Correo de Murcia en réplica a otro artículo remitido al mismo periódico, en que se censuraba la falta de patriotismo de los españoles aficionados a los libros franceses. Empieza así la respuesta: "El discurso que da principio al periódico Correo de Murcia número 109 me llenó de cólera al considerarme en la clase de sabios a la dernier, contra quienes se explica el autor con tanta acrimonia". Según "el amigo de la verdad", los malos patriotas son los incondicionales apologistas que contribuyen a la ruina de la nación intentando ocultarle sus defectos y aletargándola: "Pienso que debemos bastantes luces a la literatura extranjera, y también en otros ramos necesarios para una nación que desea y debe, a lo menos, igualarse con las demás de Europa en todo lo bueno, desechando lo malo. Y así sería de desear que la nación española tuviese a su vista lo uno y lo otro, que yo aseguro de su buena elección". Y concluye invocando la Razón: "Quitemos pues las preocupaciones, y busquémosla en cualquier parte que se hallare". ${ }^{39}$ Apenas es necezario subrayar la audacia de las anteriores líneas, cuyo autor, no contento con abogar por la introducción en España de lo bueno extranjero, llega a reclamar que la nación pueda tener a la vista "lo uno y lo otro", o sea, lo bueno y lo malo, reivindicando así un derecho a la libertad de información y de expresión de que los españoles nunca habían gozado.

Con esa posición, sostenida en diciembre de 1793 en nombre de la nueva deidad, la Razón, tocamos ya otro aspecto interesante de la prensa periódica en los años de la Revolución, y quisiera para terminar entresacar de ella algunos artículos que dejan entrever que el impacto en Es-

39. Núm. 133 (7 de diciembre de 1793), tomo IV, págs. 217-221; “La razón debe ser nucstro guía". 
paña de los sucesos de Francia no fue solamente negativo: a veces se transparenta, no ya una voluntad de resistencia a la corriente de reacción, sino cierta adhesión a los grandes principios de la Revolución francesa.

Ya que estos problemas no podían abordarse de frente, se aludía a ellos, a veces de manera muy remota, a través de controversias sobre aspectos concretos y al parecer muy limitados y anodinos de la vida social - como el respeto a los ancianos y la obediencia de los hijos a los padres-, pero enfocados con referencia a la estabilidad de las instituciones. Que el principio de la igualdad sedujera a muchos puede deducirse de unas diatribas como la siguiente de cierto "Blas Bueno", publicada en el Diario de Barcelona, a propósito de la veneración debida a los ancianos: "Aunque un buen cristiano no ignore un punto tan esencial y que es terminante en el cuarto mandamiento de la Ley de Dios, los enemigos que nos cercan intentan persuadir lo contrario y que se arranque de la memoria de los incautos toda idea de respeto y sumisión a los mayores, para inclinarlos a idolatrar la formidable bestia de una igualdad injusta y que es el origen de aquella libertad infernal que por experiencia ven transformada en la más sangrienta esclavitud. ¿Qué se seguirá de no respetar a los ancianos o mayores? Ello significaría no reconocer la menor sujeción, sacudir el yugo de las leyes más justas; e introducir el horror y confusión, hasta profanar el sagrado de los Tronos." ${ }^{90}$

También el debate acerca de la "patria potestad" se presta a generalizaciones de este tipo, cuanto más que se relaciona con la tradicional concepción de la monarquía, que equipara al soberano con el padre de familia; ${ }^{41}$ el

40. Núm. 115 (25 de abril de 1795), tomo I, págs. 457-458; "Reflexiones sobre la literatura del mes de marzo de este presente año" (Continuación).

41. "El poder paternal es la primera autoridad legítima; no ha deri- 
tema, por consiguiente, no está tan fuera de la inmediata actualidad como podría parecer. En un artículo remitido al Semanario de Salamanca a fines de 1793, Antonio Andrade del Peral intenta demostrar la falsedad de las siguientes líneas de la Enciclopedia: "Ningún hombre ha recibido de la naturaleza derecho de mandar a los otros. Si ésta ha establecido alguna autoridad, es el poder paterno, pero limitado y, en el estado de naturaleza, acabaría luego que los hijos estuvieran en estado de dirigirse a sí mismos". ${ }^{42} \mathrm{Y}$ a pocas semanas aparece otro artículo cuyo autor, que firma prudentemente "Juan", contesta al anterior: "No hay razón que convenza el poder paternal establecido por la naturaleza; y si la Enciclopedia hubiera querido decir que los padres eran señores de sus hijos, hubiera errado irremisiblemente". ${ }^{43}$ Me parece del todo evidente que debajo de la apariencia jurídica y técnica del debate, está implícito el problema de la obediencia debida al monarca por sus vasallos. Tenemos la prueba de ello en las siguientes líneas de Andrade del Peral, el defensor de la patria potestad: "Acaso se me preguntará: ¿qué debe hacer un hijo con su padre injusto y cruel? Oígase la respuesta que da un filósofo, de esta manera: "Cuando, en algunos pueblos, hay un Rey ambicioso, injusto, violento, destruidor, se le aplicará un solo remedio; que es apaciguarle con su sumisión y rogar a Dios con sus oraciones; porque éste es

rado de convención alguna, es anterior a todas ellas (...) El poder de los Reyes ha tenido su origen en el poder de los padres. Son con respecto a sus pueblos lo que los padres con respecto a sus hijos (...) El respelo y la obediencia son el homenaje de los pueblos; la vigilancia y el amor son el alma de los Reyes, La sumisión en los unos, y la autoridad en los otros formarán su duración, constitryondo su felicidad." (Semanario de Sala manca, núm. 321—9 de abril de 1796-, tomo XI, pág. 21; "Moral”.

42. Núm. 23 (17 de diciembre de 1793), tomo I, págg. 209.212; "Potentia paterna a Deo constituta est in bonum commune" (Papel remitido).

43. Núm. 31 (14 de enero de 1794), tomo II, pág. 33; "Poder paternal". 
el único remedio legítimo". Se trata, pues, de combatir las teorías del tiranicidio y de predicar la obediencia incondicional; ${ }^{45}$ por lo tanto, puede sospecharse con fundamento que los que adoptan y defienden una postura adversa a la patria potestad, como el "Juan" anteriormente citado, tienen una segunda intención: la de difundir opiniones adversas a la monarquía absoluta.

Otro problema cuyo planteamiento no es nuevo, pero que cobra un sesgo particular a consecuencia de los acontecimientos de Francia, es el de las clases sociales y de su papel dentro de la nación. Por ejemplo, me parece indudable que ciertas declamaciones contra la ociosidad de la nobleza suponen, en aquellas circunstancias, una aprobación apenas velada de la Revolución francesa, por lo menos en su fase antinobiliaria y burguesa. Así leemos bajo la pluma de un corresponsal del Diario de Barcelona: "Unos jóvenes ociosos, criados por la mayor parte en la molicie, y destituidos de todas las ideas que hacen al hombre útil a su patria, cuya soberbia y vanidad se ha fomentado desde la cuna bajo de unos principios del todo superficiales, no son más que unos zánganos, cuando no perjudiciales, a lo menos gravosos al común de sus conciudadanos"; y se evoca a continuación el ejemplo de Francia, donde esos jóvenes "no podían menos de haber emponzoñado todas las venas y ar-

44. Núm. 36 (1. de febrero de 1794), tomo II, pág. 80; “Continuación de las reflexiones sobre el poder paternal".

45. Ambos temas aparecen también claramente ligados en un artículo del Correo de Murcia (núms. 6l-30 de marzo de 1793-y 62, tomo II, págs. 202-206 y 212-214) donde se lee, pág. 212: "La primera dignidad es el uná. nime consentimiento, aun entre las naciones más bárbaras, de reverenciar y obedecer los hijos a los padrex. La segunda, la sumistón que los hombrus pleboyos manifiestan a los nobles y poderosos. La tercera, el respeto de los jóvenes a los ancianos". El artíctilo, euyo lítulo es "Discurso poltico. El principe debe dominar y sujetar a todos sus vasallos por la utilidad que resulta a la sociedad, y por ser conforme a las leyes establecídas por Dios", tue reproducido por el Semanario de Salamanca on sus números 1,2 y 3 (octubre de 1793), tomo I, págs. 1-5, 15.18 y 24-27. 
terias de su Nación". "46 Poco después aparece en el Co. rreo de Murcia un artículo titulado "La ciencia del ciudadano" - ya significa algo la terminología-, que es un alegato contra "los holgazanes de la república" y sienta el principio de que, por el derecho general de naturaleza, "todos, sin distinción de clases ni de personas, debemos dedicarnos a ser útiles a la patria", y luego, con tono casi de amenaza, alude a lo ocurrido en Francia con estas palabras: "Quisiera que muchos, convencidos de los fatales y funestos efectos que se experimentan en nuestros días, por causa de la desidia de aquellos que no quisieron dedicarse y establecerse en destino alguno, se animasen con estas breves reflexiones a proporcionarse un establecimiento útil...", ya que cn cl caso contrario deberían "ser castigados severamente" por los Magistrados. ${ }^{47}$

Lo notable en semejantes casos es que, a través de estas alusiones más o menos veladas a la Revolución francesa, ésta aparece presentada, al fin y al cabo, como consecuencia de determinada estructura social - que es también la española-, y no de un complot de los "filósofos" y francmasones. No faltan más violentas y quizás más directas referencias a las bases del antiguo régimen, aunque aducidas a propósito de problemas de corto alcance político. Veamos por ejemplo cómo, en un artículo del Correo de Murcia, partiendo de consideraciones sobre la falta de libertad y la desigualdad en la formación de los matrimonios, se llega a una impugnación apenas encubierta de los fundamentos de la sociedad estamental: "¿De dónde procede esta corrupción? ¿De dónde, sino de la falta de libertad en la elección de consorte, y aun de estado, y de las instituciones que

46. Núm. 238 (26 de agosto de 1793), tomo II, pág. 978; “Discurso sobre la educación de la juventud", firmado "E.C.Z.". Artículo reproducido en el núm. 4 del Semanario de Salamanca (12 de octubre de 1793).

47. Núm. 120 (22 de octubre de 1793), tomo IV, pág. 118; artículo firmado “Z”. 
la inducen? De aquellas instituciones que, divorciando los honores y riquezas de la aplicación y los talentos, que son sus compañeros naturales, y estancándolas en un corto número de manos, hacen que, engreídos los unos con su poder y llenos únicamente de la idea de acrecentarle, se propongan apenas otro que este fin en sus enlaces, y privan a los otros de los recursos que, si no fuera por ellos, les suministraría su industria (...) Es, pues, preciso romper las cadenas que nos aprisionan y que ellas mismas (las leyes) formaron; es preciso destruir esta odiosa alianza que formaron entre el ocio y las riquezas; es preciso, por decirlo así de una vez, dar por el pie a estas instituciones que, alterando el curso que las prescribe la naturaleza, vinculan a la mera suerte del nacer las riquezas..." ${ }^{48}$ Se trata, pues, de una aprobación inequívoca de la revolución burguesa, y de una afirmación de sus principios esenciales. Se reclama la igualdad ante la ley: "Es constante que con las buenas leyes y la emulación de los estudios honestos se gradúa la República de piadosa, justa e inviolable, que es mirada con cariño y con amor por todos sus individuos, cuando ven premiado el que lo merece y castigado el que se hizo acreedor a ello por sus delitos, tal que si esta igualdad no se observa entre los ciudadanos, ni la república será feliz, ni sus leyes serán miradas con aquel sagrado respeto y homenaje que todo racional debe tributarles"; ${ }^{49}$ y en otro texto se apunta que si falta una legislación justa y clara "los mismos que habían de ser guardas del derecho

48. Núm. 142 (7 de enero de 1794), tomo V, págs. 12-14; artículo sin título, firmado "J.F.P. de T." (Las palabras subrayadas to han silo por mí). En otro artículo publicado por el Correo de Murcia puede leerse: "Odiamos los que, constituidos en proporción de ser henéficos a la patria, y al Rey agradecidos y leales, esclavizan en la parte que puedan a sus conciu. dadanos, imponiéndoles un pesado yugo..." (Núm. 241-20 de diciembre de 1794, tomo VII, pág. 255; "Discurso sobre la nobleza", firmado "El C.S.").

49. Correo de Murcia, núm. 116 (8 de octubre de 1793), tomo IV, pág. 87. 
son dura cadena de la servidumbre del pueblo". ${ }^{50}$ Asi. mismo se reclama la igualdad ante el impuesto: "El noble que con su talento y aplicación no se ponga en estado de poder desempeñar los oficios que le corresponden como miembro principal del cuerpo político de la sociedad, conservando el honor y virtud de sus mayores, sea sujeto a pechar con los del estado llano". ${ }^{51}$ Tampoco el clero es. capa de esta crítica oblicua (aunque el caso se da con menor frecuencia); en un discurso publicado por el Memorial literario, se recuerda que los Religiosos y las Religiosas "no están menos obligados que los demás patricios a procurar la dicha del pueblo, que los sustenta con sus limosnas y su industria", y se añade, con reveladora cautela: "Mucho habría que decir; más vale dejar este punto delicado; sin embargo es preciso asegurar que, respecto del modo de pensar de la Europa, debieran los Religiosos, especialmente los monacales, arreglarse al sistema presente, haciendo ver al mundo, con sus obras, que no son ellos de la inutilidad que vociferan sus émulos..." 52

En cuanto a manifestaciones de disconformidad acerca de la estructura constitucional o propiamente política, no pueden esperarse muchas, dada la especial vigilancia de la censura en estas materias. Sólo es dado espigar alguna que otra frase alusiva, como en el extracto de un discurso de Zuazo publicado por el Memorial literario, en que, según creo, podemos ver la afirmación apenas disfrazada de la soberanía del pueblo, al decirse que la soberanía es "auto-

50. Ibid., núm, 206 (19 de agosto de 1794), tomo VI, pág. 255; de un "Discurso sobre las leyes" firmado "Z."

5). Ibid., núm. 278 (28 de abril de 1795), tomo VIII, pág. 265; continuación de un "Discurso sobre la nobleza".

52. Noviembre de 1795 (parte $1 .^{\mathbf{a}}$, tomo X, págs. 178-202; las frases citadas en las págs. 181 y 183); "Discurso dirigido a la Real Sociedad Aragonesa, donde se indican los medios de que debe valerse para promover la felicidad pública, arreglado a la constitución de aquella provincia", por el Abate Asbert. 
ridad que pertenece esencialmente al cuerpo de la Sociedad"; aunque la única conclusión que abiertamente se saca de ello es que "la autoridad soberana no se ha establecido sino por el bien común de los ciudadanos", y que, por consiguiente, corren por cuenta del Príncipe "los intereses, derechos y obligaciones" de la Nación, lo cierto es que el artículo contiene también la siguiente frase, que parece una insinuación para que la monarquía esté sobre aviso, ya que su misma permanencia está supeditada a determinadas condiciones: "Atiendan, pues, las Autoridades Soberanas, y sepan en primer lugar que su conservación depende de la recta administración de justicia y de la mayor felicidad de la sociedad". 53 Sin embargo, el mejor indicio de que existía cierto desafecto hacia la monarquía, o de que, por lo menos, se temía mucho tal desafecto, es la reiteración de los artículos destinados a afirmar la superioridad del régimen monárquico y a poner de relieve la necesidad del orden y de la jerarquía propios de este tipo de gobierno, contrastándolo con la anarquía de que daba ejemplo la Francia revolucionaria. Veamos por ejemplo cómo un tal "D.B.L.", en el Correo de Murcia, intenta convencer a sus lectores de que, con la monarquía absoluta, están gozando de la verdadera libertad: "Para que esta sociedad conserve la unión y energía de sus fuerzas, debe tener una cabeza única, indivisible, y de quien absolutamente dependa todo el poder, para emplearlo cómı y dónde convenga en el momento que lo exija la necesidad, sin oposición ni dilación que inutilice sus providencias, siendo éste el principal carácter que distingue y hace incomparablemente preferible el gobierno monárquico a todos los demás gobiernos; pues sien-

53. Enero de 1795 (parte 2.a, tomo VII, págs. 29-51; las frases citadas en las páginas 32 y 36-37); "Extracto de un discurso sobre el origen de la Magistratura, leído en la Real Academia de Derecho Español... por el licenciado don Ramón María Zuazo, en 1.0 de abril de 1794". 
do un medio entre el despótico y republicano, liberta a la nación que logra la dicha de tenerle de los desgraciados extremos de esclavitud y anarquía, que son casi inseparables de los otros gobiernos, y la constituye en el estado de felicidad y verdadera ordenada libertad que disfrutamos en nuestra España". ${ }^{44}$

Naturalmente, lo que se llama anarquía no es otra cosa que la fase democrática de la Revolución francesa, la que empieza con el triunfo del partido de "la Montaña" sobre los Girondinos en junio de 1793: en realidad una nueva revolución, por la cual, después de la nobleza, sucumbe la alta burguesía. Esta nueva orientación era apropiada para asustar a los lectores de la prensa periódica española, un público que no pertenecía enteramente a la burguesía, pero indudablemente empapado por la nueva ideología burguesa. Por eso el mismo "D.B.L." se dirige implícitamente a este sector de la opinión cuyas aspiraciones llevarían a mirar con simpatía la revolución en su fase burguesa, e intenta abrirle los ojos sobre el nuevo rumbo tomado por los acontecimientos, subrayando que ahora "vemos a los franceses preparar castigos contra los que llaman Moderados, sin más delito que querer abstraerse de las revoluciones del vulgo"; en suma, la conclusión que este autor quiere que se saque es que más vale, para la burguesía espariola, conformarse con el antiguo régimen, que no exponerse a desencadenar una revolución popular en que peligraría la seguridad de sus bienes: “...en un gobierno de esa clase no hay muralla que defienda al Ciudadano de los insultos de sus enemigos, cuando en la monarquía, viviendo todos como hijos de un mismo padre, a quien miran con la sumisión que esta dignidad trae consigo, tiene cada uno

i). Núm. 210 (2 de setiembre de 1794), tomo VII, pág. 4; "Consectario a la exhortación publicada del Excelentísimo Señor Duque de la Alcudia". 
un asilo en sus desgracias, un vengador de sus enemigos, un conservador de sus propiedades, un premiador de sus virtudes y un freno que, sujetando sus pasiones, le aparta de los precipicios que causarían indubitablemente su ruina. (...) ¿Y habrá entre nosotros alma tan pérfida que desatendiendo a la razón y a su propio interés se atreva a desear otro gobierno? Comparemos nuestra situación a la de Francia, y veamos cuál deberá preferirse. ¿Nuestras haciendas estuvieran seguras en un gobierno de esa clase? ¿Nuestras infelices mujeres, nuestros inocentes hijos, nuestros ancianos padres estarían libres de las tropelías de un Pueblo insolente?" 55

Sin embargo, no todos están dispuestos a dejarse encerrar en semejante dilema, y hay quien juzga que el mejor medio de precaverse contra los excesos de una explosión popular no es aferrarse al antiguo sistema absoluto, sino al contrario realizar por medio de una política ilustrada la necesaria evolución; otra vez vemos apuntar la idea de que, por interés propio y para su conservación-como se decía en una cita anterior-, la monarquía debe ser en adelante un gobierno ilustrado y moderado. Es lo que se desprende del análisis de un discurso de Martínez de Herbás, publicado por el Memorial literario: "La especie humana, horrorizada del sangriento espectáculo de la anarquía, sólo puede ser arrastrada por el exceso de la miseria y de la opresión a revoluciones tan temibles y tan costosas; ya se confiará en el interés paternal de los gobiernos y en el progreso de la ilustración general; ya se agitará menos sobre cuestiones abstractas, en proporción que se sientan los es-

55. Ibid, págs. 5-6. En un "Discurso sohre la parcialidad, pronunciado en el Real Consejo de las Ordenes por el Excelentisimo Señor Duque de Hijar, su presidente, en el día 2 de enero de 1794", Lambién se recalca que en Francia "se desatiende el derecho de propiedad, tan antiguo como los hombres" (Memorial literario de julio de 1794, parte 1.", tomo V, pág. 14). 
fuerzos de un ministerio justo, ocupado en consolidar la seguridad, la propiedad individual, y las leyes que las han de guarecer".56 Quizás esta frase encierre una alusión al despotismo ministerial de Godoy. Los ataques velados a la persona del valido no están ausentes de los periódicos, por ejemplo a través de unas fábulas o anécdotas que ponen en escena a un ministro indigno; en el Semanario de Salamanca se habla de uno que "era de un temperamento ardiente y de una propensión violenta a las mujeres, y nada novicio en los ardides que ganan su inclinación"; ${ }^{57}$ en el mismo periódico aparece una "Fábula oriental El buen ministro", que hace que el soberano exclame: "¡Poderoso Alá! Yo te doy las gracias porque me has dado un ministro de quien murmuran mis cortesanos y mis pueblos hablan bien" ${ }^{58}$ y en un artículo del Correo de Murcia la intención se disfraza apenas bajo un tono moralizador: "... son aplaudidos aquellos (soberanos) que usando de su magnánimo corazón supieron echar de sus palacios a aquellos hombres que no estaban poseídos de otro lenguaje que el de la adulación, y en su lugar dieron entrada a los Sabios y Filósofos prudentes, que la miraban con desprecio. (...) Dichoso el Reino que logre ver a un príncipe rodeado de sabios, a quien ni el vil interés ofusque, ni la privanza ensoberbezca". ${ }^{59}$

56. Setiembre de 1795 (parte 1.a, tomo IX, pág. 334); "Análisis del elogio del Exo. Sr. D. Antonio Ricardos... leído en la Real Sociedad de Amigos del País de Madrid, en la junta de 19 de setiembre de 1795, por el sucio de número D. Josef Martínez de Herbás".

57. Núm. 270 (10 de diciembre de 1795), tomo IX, pág. 246.

58. Núm. 250 (24 de octubre de 1795), tomo IX, pág. 87.

59. Núm. 299 (11 de julio de 1795), tomo IX, págs. 161-162; "Discurso político. Los amigos verdaderos son las riquezas de los Soberanos”, firmado "Z". 
En este ya largo recorrido por la prensa periódica española en los años cruciales de la Revolución francesa, no he pretendido dar una imagen del panorama de conjunto que ofrece su contenido; he dejado de lado muchos aspectos, como los científicos y económicos, que son, sin embargo, los que numéricamente predominan en ella y los que mejor responden quizás a su propósito fundamental: el de difundir por España los conocimientos útiles para el fomento de la agricultura, el comercio, las manufacturas, las técnicas y las ciencias. El mero hecho de que Aranda y Godoy dejaran reaparecer los periódicos con este fin no es desdeñable: nos revela que, pasado el pánico de Floridablanca, los gobernantes quisieron que se reanudase la campaña en pro de la ilustración (no olvidamos que fue en enero de 1794 cuando se inauguró el Real Instituto Asturiano). Era ya una victoria sobre los adversarios de las luces, para quienes los sucesos de Francia eran consecuencia de las nuevas ideas europeas, y que creyeron llegada la hora del aislamiento y de la reacción. Hemos visto cómo la prensa periódica, en unos principios muy prudentes, refleja esta corriente de hostilidad a todo lo francés, que envuelve-por parte de unos lectores sobre todo- una hostilidad a toda la cultura moderna; y también cómo, a pesar de aquel ambiente muy adverso, los redactores dejaron correr el temporal del período de mayor tensión y pronto mostraron las mismas aficiones que sus antecesores, expresando unos claros anhelos de reforma y de evolución. Los nuevos periódicos, en medio de la prudencia a que estaban obligados por las circunstancias y la existencia de la censura, manifiestan, a través de unos debates ideológicos, las contradicciones de una crisis en la que algunos renegaron de sus ideales de ilustración nacional. En unos momentos en que no era dable una crítica descubierta del sistema de gobierno, algunos artículos expresan sin embargo, para un lector atento, unas ideas que 
revelan la adhesión a los grandes principios de la revolu. ción burguesa, y aun insinúan, de manera indirecta y bajo la apariencia de discusiones inocentes y algo abstractas, la disconformidad de sus autores con la estructura social del antiguo régimen e incluso con el carácter absoluto de la monarquía. Algunos españoles, cuyo número no es fácil de apreciar, se apartaban así del antiguo ideal político del despotismo ilustrado (un despotismo ya más odioso porque se convertía en el de un valido), de esa concepción que defendía "el poder omnímodo del monarca" por ver en él "el nervio principal de la reforma". "Unos pocos habían entrevisto perspectivas más radicales aún y se habían convencido de que no bastaba con moderar y templar la monarquía, sino que todo el edificio tenía que ser reconstruido de nueva planta. Tarde o temprano, por medios violentos o progresivos, era inevitable que se realizara en España, como en otras partes, la revolución burguesa; y entre los que se identificaban con la ideología y las aspiraciones de la nueva clase ascendente estaban aquellos que, asustados primero por la fase democrática de la revolución vecina, se tranquilizaron luego con la fase siguiente de estabilización, que salvaguardaba a la vez las conquistas de la revolución burguesa - con la abolición de los privilegios y los derechos del hombre--y, con el orden, el derecho de propiedad, entre todos sagrado. Ya empezaban a decidirse en lo esencial las posiciones que se manifestarían unos años más tarde, en vísperas de la guerra de la Independencia, tales como las evocó Alcalá-Galiano en sus Recuerdos de un anciano: "No faltaban en España quienes soñasen en una monarquía de las llamadas constitucionales. Republicanos había ya pocos, aunque había habido bastantes entre la gente ilustrada ha-

60. Según la expresión del autor de las Cartas política-económicas al conde de Lerena (Madrid, Murillo, 1878, pág. 222). 
cia 1795, y aun hasta 1804. Pero la conversión en Imperio de la República francesa había dividido a los que, dándole culto, aspiraban a tomarla por modelo. Muchos se adherían a Napoleón, como representante de la Revolución, en su dictadura, ya consular, ya imperial; otros, mirándole como destructor de la libertad, le abominaban". ${ }^{61}$

(1) En Obras, I, B.A.E., tomo 83, pág. 23 b. 